\title{
The Functionalization of the Ultimum Remedium Principle Towards the Implementation of Criminal Actions Environmental License in the Perspective of Environmental Criminal Law in Indonesia
}

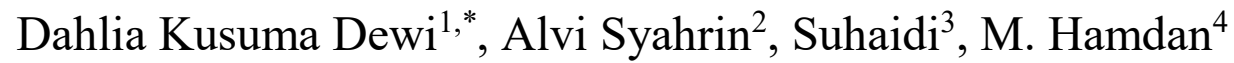 \\ ${ }^{1}$ Faculty of Law, Universitas Sumatera Utara, Medan, Indonesia, 20155 \\ 2, 3, ${ }^{4}$ Professor of the Faculty of Law, University of North Sumatra, Medan, Indonesia, 20155 \\ *Corresponding author email: alviprofdr@usu.ac.id; kesuma240284@gmail.com
}

\begin{abstract}
Environmental law is a juridical instrument for environmental management which basically includes structuring and enforcement consisting of administrative law, civil law and criminal law. Environmental law enforcement is considered a tool (an end) which functions as a statutory regulation regulating waste quality standards. In Law Number 23 of 1997 concerning Environmental Management, there are several differences with the UUPPLH Number 32 of 2009, which is the application of the subsidiarity principle of criminal law in Environmental Law Enforcement. The application of the subsidiarity principle in environmental law enforcement according to this study is not measurable, subjective and has no legal certainty. There is a debate in the settlement of environmental disputes that must be analyzed, namely whether the application of criminal law is an ultimum remidium (last resort) or a premium remidium (the main effort). The type of research is normative legal research that uses qualitative juridical analysis techniques with literature study and document observation. So from the research results it can be concluded that in formal criminal acts, the role of administrative law must be prioritized in solving environmental problems, after these efforts are ineffective, then criminal law is optimized as a last resort. This is clarified by the UUPPLH on point 6, which states that the function of criminal law against formal environmental law offenses is ultimum remedium because criminal law is a complement to administrative law and civil law. However, for serious crimes and causing public unrest, environmental criminal law is not an ultimum remedium but a premium remedium.
\end{abstract}

Keywords: Ultimum Remedium, Environmental License, Environmental Criminal Law

\section{INTRODUCTION}

Before the UUPPLH was promulgated on 3 October 2009 , the regulation of environmental problems was regulated in the UUPLH, the principle of subsidiarity was known in the UUPLH. In a general explanation it is mention that:

"In order to continue to support administrative law, the enforcement of criminal law provisions must be able to maintain the principle of subsidiarity, so that criminal law can run effectively if other legal sanctions such as administrative sanctions and civil sanctions as well as alternative environmental dispute resolution are effective and / or the level does not work properly and the law. penalties are imposed if the offender is relatively serious and / or the result of the act is relatively large, and / or the act causes public unrest".

From the general explanation, the principle of subsidiarity can be interpreted as a contrario (the opposite) that violations such as the perpetrator's mistakes are relatively not too serious, and / or administrative violations due to their actions are relatively small, and / or the perpetrators are relatively small. This action did not cause public unrest, the function of criminal law only supports administrative law and civil law as well as alternative dispute resolution. This shows that an environmental permit crime is a formal offense which is defined as an offense that has not been completed, usually formulated as can. Basically the formal offense has not polluted or damaged the environment, it has just violated the administrative law, namely violating the provisions on the prohibition of disposing of waste freely above the specified quality standards. As in The Concept of Law by H. L. A. Hart states that the principle of subsidiarity is the principle of all legislative processes and is in the midst of morals and laws. The principle of subsidiarity is usually associated with criminal law, which describes a legal nature, as the last option or tool that is well known in criminal law. Thus, criminal law is a complement to or a complement to administrative or civil law or mediation. 
Regarding the serious wrongdoing of the perpetrators and / or the result of their relatively large actions and / or their actions causing public unrest, The last criminal law to be applied is no longer the ultimum remedium but the premium remedium. The principle of subsidiarity and the principle of ultimum remedium essentially have almost the same substance, because both of these principles apply criminal law enforcement as a last resort after efforts to implement other law enforcement are ineffective, the function of criminal law is to support administrative law. The principle of ultimum remedium in the UUPPLH reinforces the meaning of the principle of subsidiarity in the UUPLH, that the optimization of criminal law on formal offenses must wait for the application of the use of administrative law to fail. Whereas in the subsidiarity principle it is not clear whether the principle applies to formal offenses or material offenses for environmental permits. However, it can be interpreted as described above, it must be related to environmental permit crimes.

The subsidiarity principle or ultimum remedium principle is stated in the general explanation, and the procedure for applying the ultimum remedium principle is contained in Article paragraph (2) of UUPPLH, this is included in the category of procedural law or procedural law or formal law. Procedural law or formal law is included in the imperative category for law enforcement officials. The legal consequences of not observing the procedural law of a process can be declared null and void.

Environmental cases that have reached the Court still use the UUPLH, because the UUPPLH was only enacted on 3 October 2009, so there are no environmental cases that use the UUPPLH. Because the two principles contain almost the same substance, namely that the enforcement of criminal law is the last resort after other law enforcement has failed to prevent environmental pollution and / or destruction, as well as supporting administrative law. Of the environmental cases submitted to the District Court, almost all ignore the existence of the principle in question. The public prosecutor always uses a material offense and a formal offense, as if the two offenses do not contain a principal difference. From the above understanding, it can be interpreted that when a public prosecutor wants to use a formal offense, he must first prove that the application of administrative law has been implemented but is not effective. Judicial practice that has occurred so far in criminal law has always been functioned as a premium remedium. The public prosecutor has never separated whether the premium remedium criminal law function can be applied to material offenses or whether it can also be imposed on formal offenses.

The application of environmental criminal law by perpetuating the existence of this principle is only considered when the defendant's advocate submits an objection or exception to the indictment of the public prosecutor. Regarding these objections or exceptions, the judges' considerations vary, in essence, they always reject the objections. From the environmental cases that have reached the Court, it can be concluded that the law in book or das sollen or the law that should have been implemented is in fact different from the law in action or das sein or the law that actually happened. The problems that will be discussed in this study are why law enforcement officers always apply environmental crime to formal environmental criminal offenses enforcement associated with the application of the ultimum remedium principle and why should the principle of subsidiarity be maintained in the Environmental Law?

\section{METHODS}

This research is a non-doctrinal study which uses a normative juridical approach that applies the law in concreto, is descriptive in nature where the type of data used is secondary data, obtained through library research.

\section{RESULT AND DISCUSSION}

\subsection{Application of Formal Offenses in Environmental Criminal Law Enforcement}

In an effort to discuss the problem, namely why law enforcement officials always apply formal crimes against environmental criminal law enforcement related to the application of the principle of ultimum remedium against formal crimes. The application of the principle of subsidiarity always places administrative legal action as part of the precedence, then the function of criminal law is carried out and not direct criminal law (criminal procedure as a supporting procedure or ultimum remedium) is also considered a guard (guard only).

This is in line with The Role of Criminal Law in The Protection of Nature and The Environmental on 3 September 1990 at the 8th UN Congress in 1990 , among others, stated that in addition to actions based on administrative law and accountability under civil law, it is also necessary to take measures 
actions against environmental problems based on criminal law.

UN member states are encouraged to implement effectively their respective national laws, including criminal laws relating to environmental protection. If nature has been damaged and / or heavily polluted, the result of the action is relatively large, and the community has been restless, then the offense is a finished offense, namely a material offense. For material offenses, the function of criminal law should be a premium remedium, therefore repressive actions can be immediately implemented. Meanwhile, the principle of subsidiarity is always associated with formal offenses, where nature has not been contaminated and / or damaged, administrative law is handled first and then criminal law is continued.

The procedure for applying formal offenses related to the principle of subsidiarity at the applicative level must be applicable to procedural law, it must be very technical, not cause multiple interpretations, seconds and be clear and can be implemented. This is because almost all law enforcement officers cannot distinguish how the application of formal and material offenses to environmental law enforcement.

This is correlated with cases of pollution and / or environmental destruction that are transferred to the Court, there is no difference in the application of formal and material offenses, as if there is no meaning of the subsidiarity principle in the UUPPLH. The existence of the principle of subsidiarity should be correlated with formal offenses that give birth to special events. The special procedural law should be obeyed in the application of the formal offense, but in the process of handling environmental cases the result is null and void.

In utilizing formal offenses in environmental criminal law, the principle of subsidiarity or the principle of ultimum remedium must be considered because it is the final or last resort after administrative law is declared null and void.

\subsection{The Importance of Maintained Subsidiarity Principle in Environmental Law}

The UUPPLH states some substantial weaknesses in the UUPLH so that improvements are needed. One of the weaknesses in the UUPLH is the unclear formulation of the subsidiarity principle. It's just that UUPPLH no longer reads the principle of subsidiarity, but has been changed to the principle of ultimum remedium. This is because the formulation of the subsidiarity principle is not clarified and is not applied in one of the UUPPLH articles, so that the concept or principle is not clear at the applicative level. And in the UUPPLH eliminates the subsidiarity principle and the ultimum remedium principle has emerged in the general explanation of number 6 , namely:

"The application of the principle of ultimum remedium based on UUPPLH only applies to certain formal crimes, namely penalties for violations of wastewater quality standards, emissions and disturbances and enforcement of environmental criminal law requires the application of criminal law enforcement as a last resort after administrative law enforcement is deemed unsuccessful".

This explanation is confirmed by Article 100 paragraph (2) that the criminal act can only be imposed if administrative sanctions are not obeyed or the violation is more than once. Formal offense violations are much more effective when using the administrative law approach when compared to criminal law. Apart from that, imprisoning perpetrators of formal offenses is far more detrimental for both the person concerned and the continuity of his business with a number of employees, as well as for the State to finance his presence in State detention centers and prisons.

From a criminal policy review, the criminalization policy against formal offenses is very unfavorable, because it ignores non-penal settlement. In fact, non-penal solutions are given a large enough space to solve the problem of criminal offenses. If non-penal measures are not effective, then criminal law will be utilized.

If the principle of subsidiarity is maintained in the UUPPLH, it can have a positive impact, namely:

1) Regarding minor environmental violations (formal offenses), let the administrative law be optimized. Then the administrative officer can monitor, provide guidance as well as provide administrative sanctions;

2) Before nature is more polluted, preventive measures can be taken. Such preventive action can be in the form of government coercion to prevent and end the occurrence of violations, as well as overcoming the consequences caused by a violation, taking action to rescue, control, and / or recover at the expense of the person in charge of the business and / or activity.

In terminology, the term preventive is an action taken at the implementation level through the arrangement of environmental quality standards for waste and / or economic instruments. 


\section{CONCLUSION}

In conclusion, the following answers can be given to the problems regarding narrative conclusions regarding the function of the ultimum remedium principle on the implementation of environmental permit crimes in the perspective of environmental criminal law in Indonesia.Based on the results of the discussion, the following conclusions were drawn:

1. Law enforcement officers do not understand the concept of implementing formal offenses in environmental criminal law and all ignore the existence of procedural law, especially environmental crimes against such formal offenses..

2. The principle of subsidiarity should indeed be maintained in the Environmental Law because the principle of subsidiarity in the UUPPLH can have a positive impact and is still relevant to be maintained.

\section{REFERENCES}

[1] HLA. Hart, The Concept Of Law, (New York: Claredon Press-Oxford, 1997), pages 36-68; HLA. Hart, The Concept Of Law, Translation (Bandung: Nusa Media, 2011) in the journal Fitrah Hamdan, PROFETIC PARADIGM:Between the Concept of Morality of the Medina Charter and the Concept of Morality H.L.A. Hart's Law, Journal of jurisprudence, Vol. 6 No. 1, March 2016.

[2] Jimly Asshiddiqie, Indonesian Constitution \& Constitutionalism, Jakarta: Secretariat General and Registrar of the Indonesian Constitution, 2006 in Nuriyanto Ahmad Daim, Urgency for Regulating State Special Institutions in the 1945 Constitution, Constitutional Journal, Vol 16, No 1 (2019).

[3] Syahrul Machmud, Indonesian Environmental Law Enforcement, Subsidiarity and Prudential Principles in Environmental Criminal Law Enforcement, Mandar Madju, Bandung, 2008, p. 51 in Prim Haryadi journal, The Development on Environmental Law Through Civil Law Enforcementin Indonesia, Journal of the Constitution, Volume 14, Number 1, March 2017.
[4] Refly Harun, Election Result Dispute Resolution in Indonesia, (Padang: PDIH FH Andalas University, Dissertation, 2016), p.21 in Refly Harun, Reconstruction of Election Result Dispute Resolution Authority, Journal of the Constitution, Vol 13, No.1 (2016)..

[5] his opinion of Indriyanto Seno Adji was expressed in his testimony in the Pre-Trial Case No. 21 / Pdt / Prap / 2004 at the South Jakarta District Court with the applicant Richard Brucee et al, prior to the promulgation of UUPPLH of the Republic of Indonesia State Sheet Year 2017 Number 182, in the journal Supramono Linggama, Implementation Of Preview Examination Related To Problems Of Detention Of Suspected By Law No. 8 Year 1981, Lex CrimenVol. VII / No. 5 / Jul / 2018.

[6] J. Suprapto, Legal and Statistical Research Methods, Rineka Cipta, Jakarta, 2000, p. 3.J. Supranto, Legal and Statistical Research Methods, Rineka Cipta, Jakarta, 2003, p. 3 in the book Ishaq, Legal Research Methods and Thesis Writing, Thesis, and Dissertation, Alfabeta Publisher, Bandung, first printing, May 2017.

[7] Soetandyo as quoted by Bachtiar, Legal Research Method, UNPAM Press, Pamulang - South Tangerang, First Edition, November 2018, there are three types of legal research that can be categorized as normative legal research, in the Anglo-American literature, namely: a. research in the form of a positive legal inventory, b. research in the form of efforts to discover the principles and basic philosophy of positive law, c. research in the form of inconcreto legal discovery efforts that are suitable to be applied in order to resolve a particular legal case.

[8] In addition, the global community has also taken the initiative to unite and equate perceptions about handling environmental problems by re-holding International Conferences on the Environment, such as the Rio De Janeiro Conference in 1992, and the 2002 Johanesburg Conference, in which the principles of environmental management produced must be integrated into in the national legal system in Adirini Pujayanti, Inter-Parliamentary Union (Ipu) And The Environment, Jurnal Politik Vol. 3, No. 1, May 2012. 
[9] De Cruz, P (2014), “Comparison of Common Law, Civil Law, and Socialist Law Systems" Publisher Nusa Media, Jakarta, pp. 61 in the Journal of RechtsVinding, Center for National Law Analysis and Evaluation, Arfan Faiz Muhlizi, Strengthening The Role Of Traditional Characters As Paralegals Providing Legal Assistance, Strengthening The Role of Indiginous People's Leader as Paralegal on Legal Aid Programm, State Law, BPHN, Cililitan Jakarta. 